\title{
Endurance exercise is a leptin signaling mimetic in hypothalamus of Wistar rats
}

Jiexiu Zhao', Ye Tian ${ }^{1 *}$, Jincheng $\mathrm{Xu}^{2}$, Dongsen Liu², Xiaofang Wang ${ }^{3}$ and Binxiu Zhao ${ }^{4}$

\begin{abstract}
Background: Endurance exercise is known to promote a substantial effect on the energy balance in rats and humans. However, little is known about the exact mechanisms for the appetite-suppressive effects of endurance exercise. We hypothesized that endurance training might activate signaling cascades in the hypothalamus known to be involved in leptin signaling.

Methods: 16 male Wistar rats were randomly assigned to two groups: sedentary $(n=8)$ and exercise groups $(n=$ 8). Animals in the exercise group started treadmill running at $30 \mathrm{~m} / \mathrm{min}, 0 \%$ grade, for $1 \mathrm{~min} /$ bout. Running time was gradually increased by $2 \mathrm{~min} /$ bout every day. The training plan was one bout per day during initial two weeks, and two bouts per day during 3rd-9th week. At the end of nine-week experiment, blood was analyzed for lowdensity lipoprotein cholesterol (LDL-C), triglyceride (TG), total cholesterol (TC), free fatty acid (FFA), interleukin (IL)-6, and leptin in both groups. Activations of janus kinase 2-signaling transducer and activator of transcription 3 (JAK2STAT3), protein kinase B (Akt), extracellular regulated kninase (ERKs), and suppressor of cytokine signaling 3 (SOCS3) in hypothalamus were measured in the end of nine weeks of exercise protocol.
\end{abstract}

Results: Nine-week endurance exercise induced lower concentrations of LDL-C, TG, TC, FFA, and leptin in rats $(P<$ 0.05 or $P<0.01$ ). Nine-week endurance exercise significantly increased the circulating IL-6 concentration compared with sedentary group $(239.6 \pm 37.2 \mathrm{pg} / \mathrm{ml}$ vs. $151.8 \pm 31.5 \mathrm{pg} / \mathrm{ml}, P<0.01)$. Exercise rats showed significant increases in JAK2, STAT3, Akt, ERKs, and SOCS3 phosphorylations compared with sedentary rats $(P<0.01)$.

Conclusion: The data suggest that endurance exercise is a leptin signaling mimetic in hypothalamus of Wistar rats. Keywords: TREADMILL, JAK2, STAT3, Akt, ERKS, SOCS3, IL-6

\section{Introduction}

There is an obesity epidemic in much of the developed and developing world [1-6]. Leptin is a cytokine originating mainly from white adipose tissue that plays an important role in regulating energy expenditure, food intake and obesity [7]. The mechanism by which leptin modulates these hypothalamic neurons involves the binding of leptin to the long form of leptin receptor $(\mathrm{Ob}-\mathrm{Rb})[8]$ and the subsequent intracellular signaling [9], initiated by autophosphorylation of Janus kinase 2 (JAK2) and activation of signal transducer and activator of transcription 2 (STAT3) [10]. After the translocation of STAT3 to the nucleus, suppressor of cytokine

\footnotetext{
* Correspondence: chinaciss2011@gmail.com

'Sport Biological Center, China Institute of Sport Science, Beijing, 100061, PR China

Full list of author information is available at the end of the article
}

signaling-3 (SOCS3) is activated, exerting feedback inhibition on JAK2 [11]. Furthermore, leptin activation of insulin receptor substrates (IRSs) and the protein kinase B (Akt) pathway inhibits food intake [12] and modulation of extracellular regulated kinases (ERKs) has been shown to play a function in the control of energy homeostasis [13]. However, leptin administration to obese rats $[14,15]$ and humans $[16,17]$ has elicited small effects on fat mass and appetite due to leptin resistance. Endurance exercise of medium intensity is known to profoundly affect energy balance [18-20]. If endurance exercise is able to activate the same signaling cascades as leptin is remains to be elucidated.

The level of circulating interleukin-6 (IL-6) increases dramatically in response to endurance exercise [21,22], with IL-6 being produced by working muscle $[23,24$ ] and adipose tissue $[25,26]$. IL- 6 seems to have several
C Biomed Central

(c) 2011 Zhao et al; licensee BioMed Central Ltd. This is an Open Access article distributed under the terms of the Creative Commons Attribution License (http://creativecommons.org/licenses/by/2.0), which permits unrestricted use, distribution, and reproduction in any medium, provided the original work is properly cited. 
important roles in metabolism, including induction of lipolysis [25,27] and enhancement of insulin sensitivity when injected into IL-6-deficient mice [28]. Thus it is possible that the effects of endurance exercise on leptin signaling pathways in hypothalamus may be dependent on IL-6.

The role of endurance training as a modulator of leptin's action has not been completely examined $[29,30]$. Endurance trained humans possess a greater capacity to oxidize fatty acid while lower concentrations of circulating leptin [31]. Another study indicated that leptin levels either expressed in absolute or relative to adiposity values are decreased with treadmill training in female Sprague-Dawley rats [32]. Taken together, it seems that endurance exercise might improve leptin sensitivity. Previous study demonstrates that sprint exercise is a leptin signaling mimetic in human skeletal muscle. However, we do not know if endurance exercise has similar mechanism in rat hypothalamus.

Therefore, the main aim of the study was to determine if a nine-week endurance exercise may act as leptin mimetic, by examining the response of the known leptin signaling pathway in hypothalamus. Another aim was to determine if nine-week endurance has positive effect on blood lipid profiles in rats. The hypothesis to be tested was that nine-week endurance exercise will activate signaling cascades in the hypothalamus known to be involved in leptin signaling pathways and that this effect will occur independently of circulating leptin concentrations.

\section{Materials and methods Animals}

Sixteen male Wistar rats (aged 2 months), was supplied by the Animal House of the Chinese Academy of Medicine, weighing $203 \pm 15 \mathrm{~g}$ were used in this experimental study. All rats were given standard rat food and tap water ad libitum and housed at $23 \pm 2^{\circ} \mathrm{C}$ on a 12:12-h dark-light cycle. The animals were divided into two groups: sedentary group $(\mathrm{n}=8)$ and exercise group $(\mathrm{n}=$ 8). Care and procedures were based on the guidelines of the National Institute of Health (NIH), and was approved by the local Animal Care and Usage Committee.

\section{Experimental protocol}

Rats in the exercise group were introduced to running on a motor driven rodent treadmill (BCPT-96, Hangzhou, China). The treadmill was equipped with an electric shocking grid on the rear barrier to provide exercise motivation to the rats. Animals of exercised groups started treadmill running at $30 \mathrm{~m} / \mathrm{min}, 0 \%$ grade, $1 \mathrm{~min} /$ bout. Running time was gradually increased by $2 \mathrm{~min} /$ bout every day. Exercise intensity of the endurance program was about $65 \%$ of maximal oxygen consumption according to previous study of oxygen consumption during a progressive exercise test in rats [33]. At the end of the nine-week experiment, the rats of exercise group were anesthetized with an intraperitoneal injection of pentobarbital sodium, $40 \mathrm{mg} / \mathrm{kg}$ of body weight, at $12 \mathrm{~h}$ after the last training. The rats of control group were anesthetized in the same time of exercise group. Epididymal, retroperitoneal, perirenal, mesenteric, andinguinal adipose depots were removed and weighed.

\section{Biochemical measurement}

At the end of experiment, blood samples were collected from abdominal aorta and drawn into capillary tubes, sealed, stored on ice, centrifuged immediately after the test, and stored at $-20^{\circ} \mathrm{C}$ for determination of related indexes. High-density lipoprotein cholesterol (HDL), low-density lipoprotein cholesterol (LDL), free fatty acid (FFA), triglyceride (TG), total and cholesterol (TC) levels were determined using commercially available kits for rats (Nanjing Jiancheng Bioengineering Institute, China). Serum leptin level was determined by radioimmunoassay kit for rats (Linco Research, St-Charles, Missouri, USA). Level of IL-6 in serum was measured with commercial enzyme-linked immunosorbent assay (ELISA) kits following the instructions of the manufacturer (RapidBio Lab, CA, USA).

\section{Western blot analysis}

The hypothalamus from exercise and sedentary groups were lysed in a lysis buffer containing $20 \mathrm{mM}$ Tris (Ph 7.4), 2 mM EDTA, $137 \mathrm{mM} \mathrm{NaCl}, 1 \% \mathrm{NP} 40,10 \%$ glycerol, $12 \mathrm{mM} \alpha$-glycerol phosphate, and supplemented protease inhibitors [34]. Protein concentration of the supernatant was measured by Bio-Rad protein assay kit (Bio-Rad Laboratories, Hercules, Calif., USA). Equal amounts of protein were used for immunoprecipitation followed by Western blot analysis with the indicated antibodies and ${ }^{125}$ I-protein A. ${ }^{125}$ I-protein $\mathrm{A}$ bound to anti-peptide antidodies was detected by autoradiography, using preflashed Kodak XAR film (Eastman Kodak, Rochester, NY) with Cronex Lightning Plus intensifying screens at $-80^{\circ} \mathrm{C}$ for $24-48 \mathrm{~h}$. Band intensities were calculated by optical densitometry of the developed autoradiographs. Antibodies for phosphorylated JAK2, STAT3, Akt, ERKs (ERK1/2), and SOCS3 were from Santa Cruz Biotechnology (Santa Cruz, CA).

\section{Quantitative real-time PCR}

Total RNA was extracted from Arcuate Nucleus (ARC) of the hypothalamus by using the single-step, acid guanidium thiocyanate, phenol-chloroform extraction as described by previous study [35]. The primer and the TaqMan probe for rat $\mathrm{Ob}-\mathrm{Rb}$ mRNA were designed 
using Primer Express software (Applied Biosystems). The nucleotide positions of the oligonucleotides were as follows. Rat's Ob-Rb (GenBank Accession No. U52966): forward primer 5'-AAAGCCTGAAACATTTGAGCATC-3', reverse primer 5'-CCAGAAGAAGAGGACCAAATATCAC-3'. The prime were searched by an NCBI BLAST homology search to ensure that they were specific for the target mRNA transcript and species. The primer of rat $\beta$-actin (internal standard) used in the real time-PCR sequences according to previous paper [36]. The real time PCR assay was performed in $50 \mu \mathrm{l}$ of Taqman One-Step RT-PCR Master Mix reagents containing $300 \mathrm{nM}$ forward primer, $900 \mathrm{nM}$ reverse primer, 200 nM TaqMan prober, and $20 \mathrm{ng}$ of total RNA. The assay was carried out using the ABI PRISM 7300 Sequence Detection System (Apllied Biosystems) under condition as follow: $95^{\circ} \mathrm{C}$ for $2 \mathrm{~min}$, followed by 45 cycles of $95^{\circ} \mathrm{C}$ for $25 \mathrm{~s}$, at $60^{\circ} \mathrm{C}$ for $25 \mathrm{~s}$, and at $72^{\circ} \mathrm{C}$ for $40 \mathrm{~s}$. The relative expression of each mRNA was calculated as the $\Delta C_{t}$ (the value obtained by subtracting the $C_{t}$ value of the $\beta$ actin from the $C_{t}$ value of the Ob-Rb mRNA).

\section{Statistical analyses}

Comparisons of body weight, food intake and fat pads in different groups were carried out using repeated measures ANOVA. Independent Student's t-test was used to analyze group difference in other variables. The results were expressed as means \pm SD. The statistical calculations were performed using SPSS software for windows (version 16.0). A probability value of $P<0.05$ was taken to be statistically significant.

\section{Results}

Effect of endurance exercise on body weight, food intake Over the full nine-week endurance exercise, exercise rats gained about $10 \%$ less body weight than did sedentary rats (Figure 1). Furthermore, nine-week endurance exercise led to a $40 \%$ reduction in total fat pad mass (Figure 1). Exercise rats failed to increase their caloric intake to compensate for their increased energy expenditure either during or after exercise termination (Figure 1).

Effect of endurance exercise on serum LDL-C, TG, TC, FFA, and leptin

Nine-week endurance exercise induced lower concentrations of LDL-C, TG, TC, FFA, and leptin compared with sedentary rats $(P<0.05$ or $P<0.01$, Table 1$)$. However, the serum IL-6 concentration was higher in the exercise group compared with sedentary group $(239.6 \pm 37.2 \mathrm{pg} / \mathrm{ml}$ vs. $151.8 \pm 31.5 \mathrm{pg} / \mathrm{ml}, P<0.01$, Table 1).

\section{Effect of endurance exercise on signaling cascades in hypothalamus}

Endurance exercise enhanced JAK2 phosphorylation in the hypothalamus $(167.5 \pm 10.9$ vs. $100.0 \pm 6.6$ arbitrary units, for exercise vs. sedentary rats, $P<0.01$, Figure 2A). Exercise group had higher STAT3 phosphorylation level than sedentary group $(178.5 \pm 16.7$ vs. $100.0 \pm 10.2$ arbitrary units, for exercised vs. sedentary groups, $P<$ 0.01 , Figure 2B). As expected, phosphorylated Akt was increased significantly in exercise group compared with sedentary group $(152.3 \pm 10.7$ vs. $100.0 \pm 9.8$ arbitrary units, for exercised vs. sedentary groups, $P<0.01$, Figure $2 \mathrm{C})$. ERKs activation was higher in exercise group compared with sedentary group $(161.3 \pm 17.1$ vs. $100.0 \pm 8.9$ arbitrary units, for exercised vs. sedentary groups, $P<$ 0.01 , Figure 2D). In addition, exercise group had higher SOCS3 phosphorylation levels that sedentary group $(213.5 \pm 16.7$ vs. $100.0 \pm 10.3$ arbitrary units, for exercised vs. sedentary groups, $P<0.01$, Figure $2 \mathrm{E}$ ).

Rats in the exercised group demonstrated significant higher (+60\%) than sedentary group in Ob-Rb mRNA concentration ( $161.5 \pm 6.3$ vs. $100.0 \pm 5.6$ arbitrary units, for exercised vs. sedentary groups, $P<0.01$, Figure 3 ).

\section{Discussion}

The present study examined changes in leptin signaling cascades in hypothalamus of Wistar rats. The major

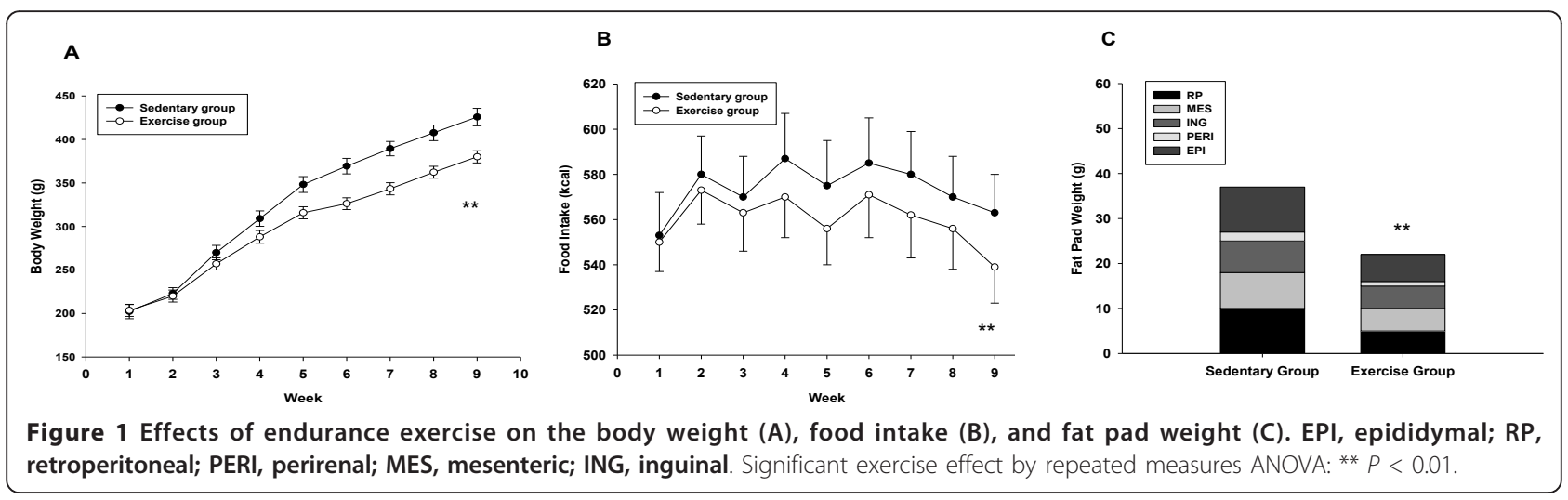


Table 1 Serum indices of lipid metabolism in sedentary and exercised rats.

\begin{tabular}{lll}
\hline & Sedentary Group & Exercise Group \\
\hline $\mathrm{HDL}-\mathrm{C}, \mathrm{mmol} / \mathrm{l}$ & $1.25 \pm 0.43$ & $1.76 \pm 1.07$ \\
$\mathrm{LDL}-\mathrm{C}, \mathrm{mmol} / \mathrm{l}$ & $2.05 \pm 0.35$ & $1.74 \pm 0.25^{*}$ \\
$\mathrm{TG}, \mathrm{mmol} / \mathrm{l}$ & $0.94 \pm 0.22$ & $0.86 \pm 0.15^{*}$ \\
$\mathrm{TC}, \mathrm{mmol} / \mathrm{l}$ & $0.82 \pm 0.20$ & $0.77 \pm 0.19^{*}$ \\
$\mathrm{FFA}, \mu \mathrm{mol} / \mathrm{l}$ & $267.9 \pm 62.8$ & $134.1 \pm 45.6^{* *}$ \\
leptin, $\mathrm{ng} / \mathrm{ml}$ & $3.7 \pm 0.8$ & $2.1 \pm 0.7 * *$ \\
IL-6, pg/ml & $151.8 \pm 31.5$ & $239.6 \pm 37.2^{* *}$ \\
\hline
\end{tabular}

Values are means \pm SD. HDL, high-density lipoprotein cholesterol; LDL, lowdensity lipoprotein cholesterol; TG, triglyceride; TC, total cholesterol; FFA, free fatty acid; IL-6, interleukin-6. Significant difference from sedentary group, * $P<$ $0.05, * * P<0.01$

finding of this study is nine-week endurance exercise resulted in significant decreases in the body weight, food intake, and fat pad weight (Figure 1). In agreement with our hypothesis, nine-week endurance exercise increased Ob-Rb mRNA expression (Figure 3) and signaling cascades (Figure 2) in the hypothalamus compared with sedentary group. The changes in signaling pathways occurred with same changes in circulating IL-6 concentrations in exercise rats. However, circulating leptin concentration was decreased in exercise group compared with sedentary group (Table 1). Altogether, these results indicate that nine-week endurance performed leptin mimetic in hypothalamus of rats.

Effect of endurance exercise on fat mass and serum LDLC, TG, TC, FFA

The present study indicated that endurance exercise induced reduction in fat mass in rats compared with sedentary rats. This results is similar to previous reports in rats [37] and mice [38]. Along with fat mass indexes, we monitored the major parameters of lipid metabolism. The results showed that concentrations of LDL-C, TG, $\mathrm{TC}$, and FFA decreased significantly after endurance exercise $(P<0.05$ or $P<0.01)$. This finding is in line with other endurance training and FFA studies, showing that endurance training results in significant improvements in FFA mobilization and oxidation [39]. Therefore, it seems that endurance exercise has positive effect on adipose tissue metabolism in rats.

\section{Effect of endurance exercise on signaling cascades in hypothalamus}

There is recent evidence that hypothalamic leptin signal pathway and $\mathrm{Ob}-\mathrm{Rb}$ are reliable indexes to reflect adiposity levels $[40,41]$. However, the effect of endurance exercise on hypothalamic leptin signaling and $\mathrm{Ob}-\mathrm{Rb}$ mRNA is unknown. In an effort to fill this gap, the present work measured seven biological parameters (with the emphasis on leptin sinaling and Ob-Rb mRNA) after nine-week endurance exercise. In contrast to non-Arcuate Nucleus (ARC) long form Ob-Rb neurons, ARC long form $\mathrm{Ob}-\mathrm{Rb}$ neurons might directly access circulating leptin [42]. We can predict that the ARC is an excellent sensor of peripheral metabolism of leptin. In this context, it seems that ARC of the hypothalamus is one of the key organs involved in leptin action. Our data show that Ob-Rb mRNA of hypothalamus ARC was increased significantly and circulating leptin was decreased significantly by the endurance exercise. The results support previous hypothesis that training by decreasing plasma leptin levels may favor the peripheral action of leptin through the hypothalamic centers [43]. These findings agree with another study $[43,44]$. They found that endurance exercise induced decreases in plasma leptin levels is accompanied by a reduction in gene expression of leptin receptors in liver. Based on the information, it is possible that endurance exercise reinforces the central rather than peripheral action of leptin. On the other hand, one study showed that muscle hypertrophy and increased expression of leptin receptors in the musculus triceps brachii of the dominant arm in professional tennis players [45]. It seems to us that conflicting results in the literature may stem from two sources primarily. One is intrinsic limitation of different subjects and different tissues of the Ob-Rb mRNA. The subjects in study of Olmedillas et al. are tennis players and muscle tissues were measured for $\mathrm{Ob}-\mathrm{Rb}$ mRNA. However, we chose rats as subjects and hypothalamuses were measured for $\mathrm{Ob}-\mathrm{Rb}$ mRNA. Another is different exercise mode. Endurance exercise was taken in present study, while tennis was taken in the study of different results [45]. However, it is imperative that future studies examine the expression of the $\mathrm{Ob}-\mathrm{Rb}$ protein in hypothalamus and its relationship to leptin singing pathway.

Regulation of energy balance is an essential function of the human organism that is controlled by the central nervous system and an elaborate interplay of intertissue signaling [44]. IL-6 is one peptide hormone that could supply peripheral feedback to the hypothalamus [44], and contributes to substrate availability and utilization by facilitating an increase in glucose and lipid metabolism to maintain metabolic homeostasis during endurance exercise [46]. IL-6 peripheral signal activates several hypothalamic hormonal pathways during training [47]. It is clear that during endurance exercise, IL-6 can be produced and released from skeletal muscle tissue [48]. This is likely the reason why the circulating IL-6 is increased after nine-week endurance exercise in our study.

Our data provide evidence that there is an increase in the JAK2, STAT3, Akt, ERKs, and SOCS3 signaling cascades (Figure 2). Leptin activation of STAT3 

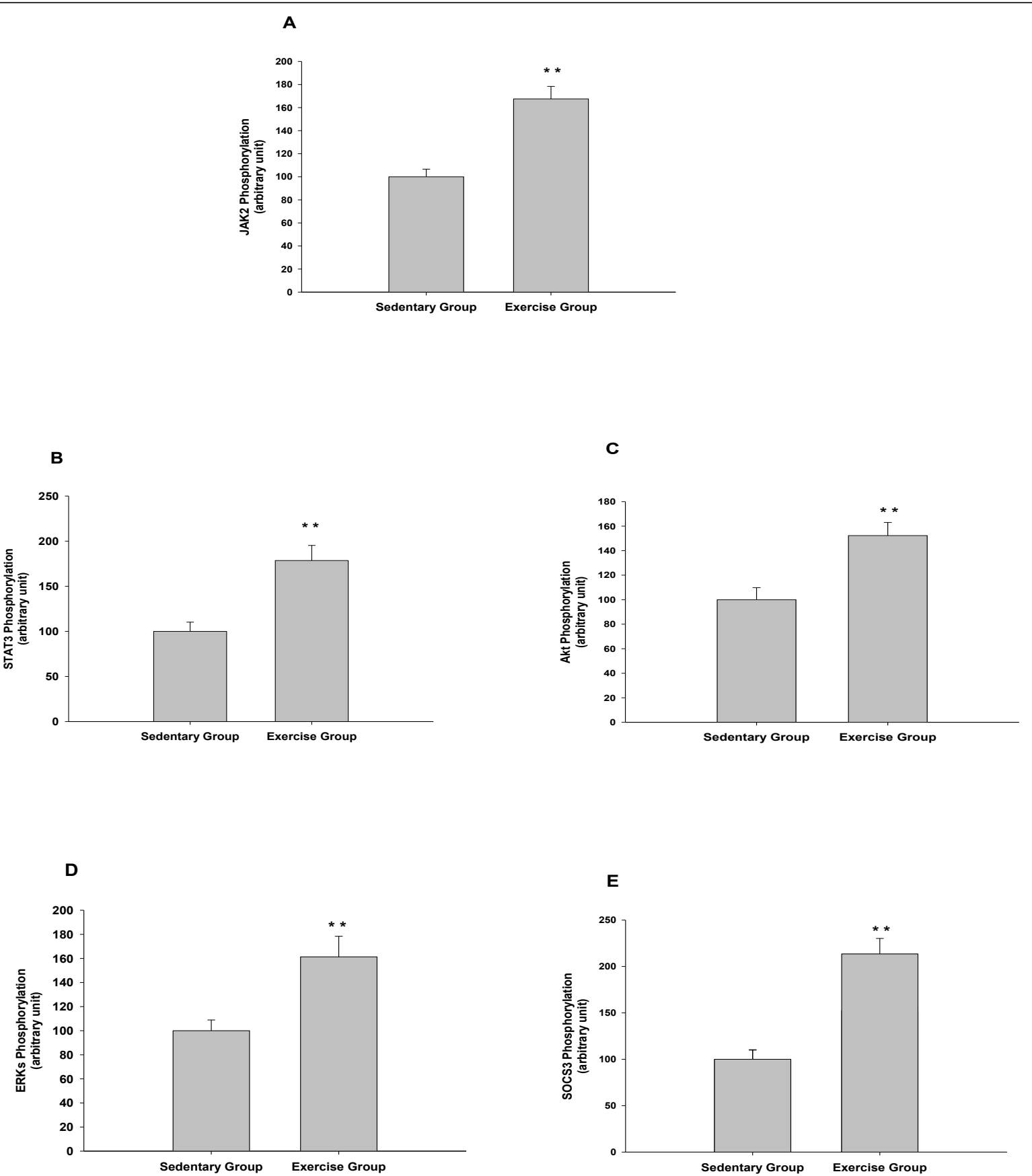

Figure 2 Effects of endurance exercise on the signaling cascades in hypothalamus. (A) JAK2 phosphorylation concentrations in exercise and sedentary groups. (B) STAT3 phosphorylation levels in exercise and sedentary groups. (C) Akt phosphorylation levels in exercise and sedentary groups. (D) ERKs phosphorylation levels in exercise and sedentary groups. (E) SOCS3 phosphorylation levels in exercise and sedentary groups. Signaling phosphorylations were normalized to total signaling, and levels in sedentary rats were set to 100 , with SD adjusted proportionally. ${ }^{* *} P<0.01$ vs. sedentary rats.

requires the leptin receptor, which associates with and activates JAK2 in a ligand-dependent manner $[49,50]$. The current study provide direct measurements of leptin signaling in the hypothalamus after endurance exercise, and it documents increased sensitivity to
JAK2/STAT3 pathway in the hypothalamus of exercised rats. ERKs may be phosphorylated directly by JAK2, i.e., by an OB-Rb-independent mechanism [51]. Our results are in line with previous studies that endurance exercise can induce ERKs phosphorylation 


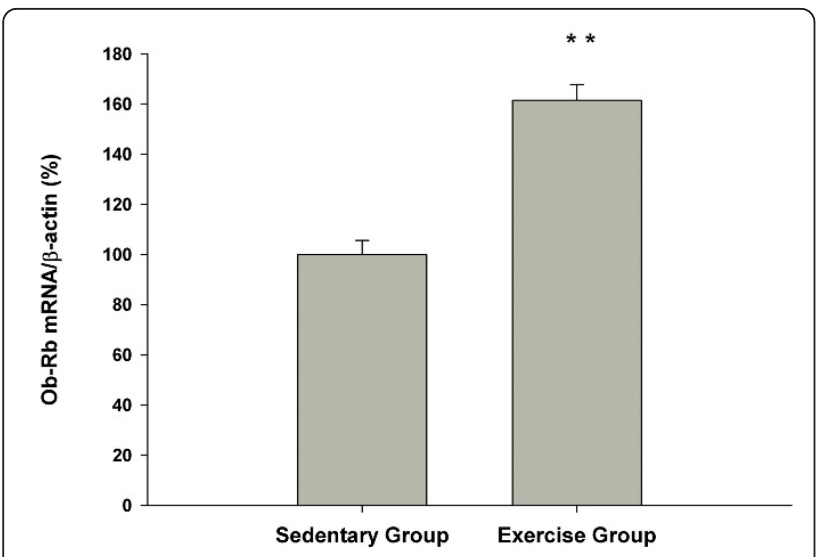

Figure 3 Effect of exercise on the expression of Ob-Rb mRNA quantified relative to $\beta$-actin in hypothalamus. Concentrations in sedentary rats were set to 100 , with SD adjusted proportionally. ${ }^{*} P$ $<0.01$ vs. sedentary rats.

[52-54]. Endurance exercise could increase SOCS3 expression in rats and the change has potential relationship to IL-6 expression [55]. Our results also imply that increased SOCS3 is caused by higher IL-6 concentrations induced by endurance exercise. Little is known about the potential effect of endurance exercise on Akt. These finding provides support for the hypothesis that endurance exercise could have appetite-suppressive actions mediated by the hypothalamus. Although JAK2, STAT3, Akt, ERKs, and SOCS3 are signaling cascades of leptin, decreased leptin concentrations and increased signaling cascades after nine-week endurance exercise implying that circulating leptin could hardly explain the observed responses of signaling phosphorylations in hypothalamus. Higher increases in circulating IL- 6 are needed to induce STAT3 and SOCS3 phosphorylation $[55,56]$. It is possible that increased circulating IL-6 could easily explain the increased singling levels in hypothalamus of exercise rats compared with sedentary rats.

In conclusion, this study demonstrates that the signaling pathways activated by leptin in hypothalamus are also activated by nine-week endurance exercise in hypothalamus of Wistar rats, despite a reduction of leptin serum concentration after the endurance exercise. These finding imply that endurance behave as a leptin mimetic and could be used to stimulate the leptin signaling pathway in haypothalamus of Wistar rats. This opens the possibility of using endurance exercise to circumvent leptin resistance in obese humans and rats and may lead to increased leptin sensitivity. We provide some evidences to support that the effects of endurance exercise on JAK2, STAT3, Akt, ERKs, and SOCS 3 are mediated by change in serum IL-6 concentration.

\section{Acknowledgements}

This work was supported by National Natural Science Foundation of China (30270642) and Foundation of China Society of Sport Science (2005-04). The author wished to thank Genomics \& Bioinformatics Center Chinese Academy of Science for technical assistance.

\section{Author details}

${ }^{1}$ Sport Biological Center, China Institute of Sport Science, Beijing, 100061, PR China. ${ }^{2}$ Departments of Kinesiology, Beijing Sport University, Beijing, 100084, PR China. ${ }^{3}$ Department of Biomedical Sciences, Baylor College of Dentistry, Texas A \& M University System Health Science Center, Dallas, TX, 75246, USA. ${ }^{4}$ First People's Hospital of Shijiazhuang, Hebei, 050011, PR China.

\section{Authors' contributions}

$J X Z$ and $Y T$ have conceived the study and its design and obtained research grants for this study. JCX, DSL, JXZ, XFW, and BXZ have analyzed the date, interpreted and written the final draft of this manuscript. All authors have read and approved the final manuscript.

\section{Competing interests}

The authors declare that they have no competing interests.

Received: 24 November 2011 Accepted: 2 December 2011 Published: 2 December 2011

\section{References}

1. Ford ES, Giles WH, Mokdad AH: Increasing prevalence of the metabolic syndrome among u.s. Adults. Diabetes Care 2004, 27:2444-2449.

2. Hu G, Lindstrom J, Jousilahti P, Peltonen M, Sjoberg L, Kaaja R, Sundvall J, Tuomilehto J: The increasing prevalence of metabolic syndrome among Finnish men and women over a decade. J Clin Endocrinol Metab 2008, 93:832-836.

3. Lim S, Shin H, Song JH, Kwak SH, Kang SM, Won Yoon J, Choi SH, Cho SI, Park KS, Lee HK, et al: Increasing prevalence of metabolic syndrome in Korea: the Korean National Health and Nutrition Examination Survey for 1998-2007. Diabetes Care 2011, 34:1323-1328.

4. Popkin BM: The nutrition transition and obesity in the developing world. J Nutr 2001, 131:871S-873S.

5. Kimokoti RW, Millen BE: Diet, the global obesity epidemic, and prevention. J Am Diet Assoc 2011, 111:1137-1140.

6. Shao Q, Chin KV: Survey of American food trends and the growing obesity epidemic. Nutr Res Pract 2011, 5:253-259.

7. Zhang Y, Proenca R, Maffei M, Barone M, Leopold L, Friedman JM: Positional cloning of the mouse obese gene and its human homologue. Nature 1994, 372:425-432.

8. Tartaglia LA, Dembski M, Weng X, Deng N, Culpepper J, Devos R, Richards GJ, Campfield LA, Clark FT, Deeds J, et al: Identification and expression cloning of a leptin receptor, OB-R. Cell 1995, 83:1263-1271.

9. Abizaid A, Horvath TL: Brain circuits regulating energy homeostasis. Regul Pept 2008, 149:3-10.

10. Robertson SA, Leinninger GM, Myers MG Jr: Molecular and neural mediators of leptin action. Physiol Behav 2008, 94:637-642.

11. Bjorbaek C, El-Haschimi K, Frantz JD, Flier JS: The role of SOCS-3 in leptin signaling and leptin resistance. J Biol Chem 1999, 274:30059-30065.

12. Niswender KD, Baskin DG, Schwartz MW: Insulin and its evolving partnership with leptin in the hypothalamic control of energy homeostasis. Trends Endocrinol Metab 2004, 15:362-369.

13. Rahmouni K, Sigmund CD, Haynes WG, Mark AL: Hypothalamic ERK mediates the anorectic and thermogenic sympathetic effects of leptin. Diabetes 2009, 58:536-542.

14. Collier GR, De Silva A, Sanigorski A, Walder K, Yamamoto A, Zimmet P: Development of obesity and insulin resistance in the Israeli sand rat (Psammomys obesus). Does leptin play a role? Ann N Y Acad Sci 1997, 827:50-63.

15. de Oliveira E, Moura EG, Santos-Silva AP, Pinheiro CR, Lima NS, NogueiraNeto JF, Nunes-Freitas AL, Abreu-Villaca Y, Passos MC, Lisboa PC: Neonatal nicotine exposure causes insulin and leptin resistance and inhibits hypothalamic leptin signaling in adult rat offspring. J Endocrinol 2010, 206:55-63.

16. Eikelis N, Wiesner G, Lambert G, Esler M: Brain leptin resistance in human obesity revisited. Regul Pept 2007, 139:45-51. 
17. Sarigianni M, Bekiari E, Tsapas A, Kaloyianni M, Koliakos G, Paletas K: Effect of leptin and insulin resistance on properties of human monocytes in lean and obese healthy participants. Angiology 2010, 61:768-774.

18. Bergouignan A, Momken I, Schoeller DA, Normand S, Zahariev A, Lescure B, Simon C, Blanc S: Regulation of energy balance during long-term physical inactivity induced by bed rest with and without exercise training. J Clin Endocrinol Metab 2010, 95:1045-1053.

19. Whybrow S, Hughes DA, Ritz P, Johnstone AM, Horgan GW, King N, Blundell JE, Stubbs RJ: The effect of an incremental increase in exercise on appetite, eating behaviour and energy balance in lean men and women feeding ad libitum. Br J Nutr 2008, 100:1109-1115.

20. Loucks AB: Energy balance and body composition in sports and exercise. J Sports Sci 2004, 22:1-14.

21. Pedersen BK, Hoffman-Goetz L: Exercise and the immune system: regulation, integration, and adaptation. Physiol Rev 2000, 80:1055-1081.

22. Libardi CA, de Souza GV, Cavaglieri CR, Madruga VA, Chacon-Mikahil MP: Effect of Resistance, Endurance and Concurrent Training on TNF-alpha, IL-6 and CRP. Med Sci Sports Exerc 2011

23. Penkowa $M$, Keller $C$, Keller $P$, Jauffred $S$, Pedersen BK: Immunohistochemical detection of interleukin- 6 in human skeletal muscle fibers following exercise. FASEB J 2003, 17:2166-2168.

24. Steensberg A, van Hall G, Osada T, Sacchetti M, Saltin B, Klarlund Pedersen B: Production of interleukin- 6 in contracting human skeletal muscles can account for the exercise-induced increase in plasma interleukin-6. J Physiol 2000, 529 Pt 1:237-242.

25. Lyngso D, Simonsen L, Bulow J: Interleukin-6 production in human subcutaneous abdominal adipose tissue: the effect of exercise. J Physiol 2002, 543:373-378

26. Keller C, Keller P, Marshal S, Pedersen BK: IL-6 gene expression in human adipose tissue in response to exercise-effect of carbohydrate ingestion. J Physiol 2003, 550:927-931.

27. Maffei M, Halaas J, Ravussin E, Pratley RE, Lee GH, Zhang Y, Fei H, Kim S, Lallone $R$, Ranganathan $S$, et al: Leptin levels in human and rodent: measurement of plasma leptin and ob RNA in obese and weightreduced subjects. Nat Med 1995, 1:1155-1161.

28. Wallenius V, Wallenius $\mathrm{K}$, Ahren B, Rudling M, Carlsten H, Dickson SL, Ohlsson C, Jansson JO: Interleukin-6-deficient mice develop mature-onset obesity. Nat Med 2002, 8:75-79.

29. Steinberg GR, Smith AC, Wormald S, Malenfant P, Collier C, Dyck DJ: Endurance training partially reverses dietary-induced leptin resistance in rodent skeletal muscle. Am J Physiol Endocrinol Metab 2004, 286:E57-63.

30. Moran CN, Barwell ND, Malkova D, Cleland SJ, McPhee I, Packard CJ, Zammit VA, Gill JM: Effects of diabetes family history and exercise training on the expression of adiponectin and leptin and their receptors. Metabolism 2011, 60:206-214.

31. Perusse L, Collier G, Gagnon J, Leon AS, Rao DC, Skinner JS, Wilmore JH, Nadeau A, Zimmet PZ, Bouchard C: Acute and chronic effects of exercise on leptin levels in humans. J Appl Physiol 1997, 83:5-10.

32. Gauthier MS, Couturier K, Charbonneau A, Lavoie JM: Effects of introducing physical training in the course of a 16-week high-fat diet regimen on hepatic steatosis, adipose tissue fat accumulation, and plasma lipid profile. Int J Obes Relat Metab Disord 2004, 28:1064-1071.

33. Bedford TG, Tipton CM, Wilson NC, Oppliger RA, Gisolfi CV: Maximum oxygen consumption of rats and its changes with various experimental procedures. J Appl Physiol 1979, 47:1278-1283.

34. Friedman JE, Ferrara CM, Aulak KS, Hatzoglou M, McCune SA, Park S, Sherman WM: Exercise training down-regulates ob gene expression in the genetically obese SHHF/Mcc-fa(cp) rat. Horm Metab Res 1997, 29:214-219.

35. Chomczynski P, Sacchi N: Single-step method of RNA isolation by acid guanidinium thiocyanate-phenol-chloroform extraction. Anal Biochem 1987, 162:156-159.

36. Yamaguchi M, Yamauchi A, Nishimura M, Ueda N, Naito S: Soybean oil fat emulsion prevents cytochrome P450 mRNA down-regulation induced by fat-free overdose total parenteral nutrition in infant rats. Biol Pharm Bull 2005, 28:143-147.

37. Patterson CM, Dunn-Meynell AA, Levin BE: Three weeks of early-onset exercise prolongs obesity resistance in DIO rats after exercise cessation. Am J Physiol Regul Integr Comp Physiol 2008, 294:R290-301.
38. Mayer J, Marshall NB, Vitale JJ, Christensen JH, Mashayekhi MB, Stare FJ: Exercise, food intake and body weight in normal rats and genetically obese adult mice. Am J Physiol 1954, 177:544-548.

39. Johnson ML, Zarins Z, Fattor JA, Horning MA, Messonnier L, Lehman SL, Brooks GA: Twelve weeks of endurance training increases FFA mobilization and reesterification in postmenopausal women. $J$ App/ Physiol 2010, 109:1573-1581.

40. Ailhaud $\mathrm{G}$ : Adipose tissue as a secretory organ: from adipogenesis to the metabolic syndrome. C R Biol 2006, 329:570-577; discussion 653-575.

41. Ovilo C, Fernandez A, Fernandez Al, Folch JM, Varona L, Benitez R, Nunez $Y$, Rodriguez C, Silio L: Hypothalamic expression of porcine leptin receptor (LEPR), neuropeptide Y (NPY), and cocaine- and amphetamine-regulated transcript (CART) genes is influenced by LEPR genotype. Mamm Genome 2010, 21:583-591.

42. Munzberg H: Differential leptin access into the brain-a hierarchical organization of hypothalamic leptin target sites? Physiol Behav 2008, 94:664-669.

43. Yasari S, Wang D, Prud'homme D, Jankowski M, Gutkowska J, Lavoie JM: Exercise training decreases plasma leptin levels and the expression of hepatic leptin receptor-a, -b, and, -e in rats. Mol Cell Biochem 2009, 324:13-20.

44. Jurimae J, Maestu J, Jurimae T, Mangus B, von Duvillard SP: Peripheral signals of energy homeostasis as possible markers of training stress in athletes: a review. Metabolism 2011, 60:335-350

45. Olmedillas H, Sanchis-Moysi J, Fuentes T, Guadalupe-Grau A, PonceGonzalez JG, Morales-Alamo D, Santana A, Dorado C, Calbet JA, Guerra B: Muscle hypertrophy and increased expression of leptin receptors in the musculus triceps brachii of the dominant arm in professional tennis players. Eur J Appl Physiol 2010, 108:749-758.

46. Cox AJ, Pyne DB, Cox GR, Callister R, Gleeson M: Pre-exercise carbohydrate status influences carbohydrate-mediated attenuation of post-exercise cytokine responses. Int I Sports Med 2008, 29:1003-1009.

47. Steinacker JM, Lormes W, Reissnecker S, Liu Y: New aspects of the hormone and cytokine response to training. Eur J Appl Physiol 2004, 91:382-391.

48. Ostrowski K, Rohde T, Zacho M, Asp S, Pedersen BK: Evidence that interleukin-6 is produced in human skeletal muscle during prolonged running. J Physiol 1998, 508(Pt 3):949-953.

49. Baumann H, Morella KK, White DW, Dembski M, Bailon PS, Kim H, Lai CF, Tartaglia LA: The full-length leptin receptor has signaling capabilities of interleukin 6-type cytokine receptors. Proc Natl Acad Sci USA 1996, 93:8374-8378.

50. Ghilardi N, Ziegler S, Wiestner A, Stoffel R, Heim MH, Skoda RC: Defective STAT signaling by the leptin receptor in diabetic mice. Proc Natl Acad Sci USA 1996, 93:6231-6235.

51. Banks AS, Davis SM, Bates SH, Myers MG Jr: Activation of downstream signals by the long form of the leptin receptor. J Biol Chem 2000, 275:14563-14572.

52. Aronson D, Violan MA, Dufresne SD, Zangen D, Fielding RA, Goodyear L: Exercise stimulates the mitogen-activated protein kinase pathway in human skeletal muscle. J Clin Invest 1997, 99:1251-1257.

53. Goodyear LJ, Chang PY, Sherwood DJ, Dufresne SD, Moller DE: Effects of exercise and insulin on mitogen-activated protein kinase signaling pathways in rat skeletal muscle. Am J Physiol 1996, 271:E403-408.

54. Yu M, Blomstrand E, Chibalin AV, Krook A, Zierath JR: Marathon running increases ERK $1 / 2$ and p38 MAP kinase signalling to downstream targets in human skeletal muscle. J Physiol 2001, 536:273-282.

55. Spangenburg EE, Brown DA, Johnson MS, Moore RL: Exercise increases SOCS-3 expression in rat skeletal muscle: potential relationship to IL-6 expression. J Physiol 2006, 572:839-848.

56. Wolsk E, Mygind H, Grondahl TS, Pedersen BK, van Hall G: IL-6 selectively stimulates fat metabolism in human skeletal muscle. Am J Physiol Endocrinol Metab 2010, 299:E832-840.

doi:10.1186/1476-511X-10-225

Cite this article as: Zhao et al.: Endurance exercise is a leptin signaling mimetic in hypothalamus of Wistar rats. Lipids in Health and Disease 2011 10:225 